\title{
Factors associated with adherence to antihypertensive treatment in a primary care unit*
}

\author{
Fatores associados à adesão ao tratamento anti-hipertensivo em unidade básica de saúde \\ Factores asociados con la adhesión al tratamiento antihipertensivo en unidad de salud
}

\author{
Márcia Simonia Demoner, Edivan Rodrigo de Paula Ramos ${ }^{2}$, Eliane Ramos Pereira ${ }^{3}$
}

\begin{abstract}
Objectives: To analyze the adherence of patients to antihypertensive treatment conducted in a Primary Care Unit (PCU), as well as the related factors of low adherence to this therapy. Methods: A quantitative, descriptive exploratory study of hypertensive patients interviewed in a PCU, using the Morisky-Green Test for assessing adherence or nonadherence with antihypertensive treatment. Results: A prevalence of $64 \%$ of patients who were nonadherent to antihypertensive therapy was identified, and this was significantly related to the variables of: age, occupation, obesity, lack of other chronic disease, lack of employment, continuous use of prescription drugs, misunderstanding of the medical recommendations, and ignorance of the name of antihypertensive medication use. Conclusion: We found a high prevalence (64\%) of patients nonadherent to therapy, that was significantly associated with users who were: in the youngest age group, working, and presenting with overweight or obesity. Keywords: Patient compliance; Hypertension/therapy; Antihypertensive agents; Health education
\end{abstract}

\section{RESUMO}

Objetivos: Analisar a adesão de pacientes ao tratamento anti-hipertensivo realizado em uma Unidade Básica de Saúde (UBS), assim como os fatores relacionados à baixa adesão a essa terapia. Métodos: Estudo de natureza quantitativa, exploratório descritivo com amostra de 150 pacientes hipertensos entrevistados em uma UBS, utilizando-se o Teste de Morisky-Green para avaliação da adesão ou não ao tratamento anti-hipertensivo. Resultados: Uma prevalência de 64\% de pacientes não aderentes à terapia anti-hipertensiva foi identificada que esteve significativamente associada às variáveis: faixa etária, ocupação, obesidade, ausência de outra doença crônica, falta de emprego de medicamentos de uso contínuo, incompreensão das recomendações médicas e o desconhecimento do nome do medicamento anti-hipertensivo utilizado. Conclusão: Constatou-se elevada prevalência de $64 \%$ de pacientes não aderentes à terapia que, foi significativamente associada aos usuários de faixa etária mais jovem, que trabalham, com sobrepeso ou obesidade.

Descritores: Cooperação do paciente; Hipertensão/terapia; Anti-hipertensivos; Educação em saúde

\section{RESUMEN}

Objetivos: Analizar la adhesión de pacientes al tratamiento anti-hipertensivo realizado en una Unidad Básica de Salud (UBS), así como los factores relacionados a la baja adhesión a esa terapia. Métodos: Estudio de naturaleza cuantitativa, exploratoria descritiva realizado con una muestra de 150 pacientes hipertensos entrevistados en una UBS, utilizándose el Test de Morisky-Green para la evaluación de la adhesión o no al tratamiento anti-hipertensivo. Resultados: Fue identificada una prevalencia del $64 \%$ de pacientes no adherentes a la terapia anti-hipertensiva que estuvo significativamente asociada a las variables: grupo etáreo, ocupación, obesidad, ausencia de otra enfermedad crónica, falta de empleo de medicamentos de uso contínuo, incomprensión de las recomendaciones médicas y el desconocimiento del nombre del medicamento anti-hipertensivo utilizado. Conclusión: Se constato una elevada prevalencia del $64 \%$ de pacientes no adherentes a la terapia que, fue significativamente asociada a los usuarios Del grupo estáreo más joven, que trabajan, con sobrepeso u obesidad.

Descriptores: Cooperación del paciente; Hipertensión/terapia; Antihipertensivos; Educación en salud

\footnotetext{
* Study extracted from the research of conclusion of course of specialization entitled "Characterization of adherence to drug therapy of hypertensive patients in a primary health care unit" - presented to the Postgraduate Course in Clinical Pharmacology, University Center, Maringá - CESUMAR - Maringa (PR), Brazil. ${ }^{1}$ Degree in Nursing. Specialist in Clinical Pharmacology. Universidade Maringá - CESUMAR - Maringá (PR) Brazil.

${ }^{2}$ Master's in Pharmaceutical Sciences. Adjunct Professor, Universidade Maringá - CESUMAR - Maringá (PR) Brazil.

${ }^{3}$ Post-Doctorate in Nursing. State University of Rio de Janeiro - UERJ - Rio de Janeiro (RJ), Brazil; Associate Professor, School of Nursing, Universidade Federal Fluminense-UFF-Niterói (RJ) Brazil.
} 


\section{INTRODUCTION}

Systematic arterial hypertension (HTN) is considered a disease of high prevalence and low control, and its inadequate treatment can lead to coronary heart disease (CHD), acute myocardial infarction (AMI), peripheral vascular disease (PVD), stroke (CVA), congestive heart failure and renal failure. Because of these consequences, HTN is responsible for about 7.6 million deaths worldwide ${ }^{(1-3)}$.

Epidemiological data obtained in more than 25 countries indicate that in 2025 , one billion, nine hundred seventy-two million people aged 18 to 91 years will present with HTN. However, this number may be even higher, because it is an asymptomatic disease and it is therefore under diagnosed ${ }^{(2,4-5)}$.

In Brazil, a third of all deaths and $65 \%$ of deaths in people aged between 30 and 69 years are due to cardiovascular diseases. As for HTN, it is estimated that approximately 17 million Brazilians have the disease ${ }^{(2,6-7)}$. From 2002 to 2008, HTN had a considerable increase in its incidence, and during the year of 2008 , more than 19,000 deaths occurred ${ }^{(8)}$. Although HTN is considered a disease of multifactorial etiology, certain risk factors are more relevant. Among these are: age, gender, race / ethnicity, overweight and obesity, excessive intake of salt and alcohol for a long period of time, sedentary lifestyle, smoking, socioeconomic factors, education and genetics ${ }^{(1-6,9)}$.

Because of the high morbidity and mortality resulting from complications caused by HTN, it is necessary for the patient to have adequate control of his/her blood pressure (BP) through the use of pharmacological and non-pharmacological therapies. Non-pharmacological therapy involves changes in lifestyle that emphasize the regular practice of physical activity, weight loss, a diet low in sodium and fat, no consumption of alcohol, no smoking, and stress management. Such simple measures in healthy patients may delay the onset of this disease ${ }^{(10)}$.

Pharmacological therapy may be performed with a variety of classes of antihypertensive medications and their combinations. These treatment groups are represented by diuretics, drugs that reduce the activity of the renin-angiotensin-aldosterone system, direct action vasodilators, beta-blockers, and sympatholytic drugs with central and peripheral action ${ }^{(11)}$.

Despite the arsenal of anti-hypertensive medications, health professionals continue to encounter a serious problem: the lack of adherence to therapy, whether it is medication or another treatment ${ }^{(12)}$. Adherence to treatment is complex and several factors may be associated, depending on user characteristics and the disease, cultural and life habits, medication treatment, institutional difficulties, and also, problems related to the health care team ${ }^{(13)}$.

Considering that HTN is a difficult disease for adherence to treatment due to the required change in lifestyle habits and active participation of the individual in antihypertensive medication therapy ${ }^{(2)}$, we consider that the knowledge about adherence and these factors and their relationships can guide facilitating actions for greater adherence ${ }^{(1,2)}$.

Accordingly, the present study had the objectives of analyzing the adherence of patients to antihypertensive treatment performed in a Primary Care Unit (PCU), as well as factors related to poor adherence to this therapy.

\section{METHODS}

This was a quantitative, exploratory and descriptive study, developed in a PCU that attended to, among others, 432 patients with hypertension, in the city of Maringá (PR), within an upper middle class neighborhood, of approximately 5753 residents. This PCU has teams of the Family Health Program (FHP) services are provided by professionals from the Support Center for Family Health.

The research sample consisted of 150 patients with HTN monitored by this PCU, who were selected randomly and, after being welcomed, were invited to participate in the study. The data collection occurred in the waiting room while users were awaiting medical consultation. The study sample included individuals over 18 years of age, who had hypertension treated with medications. We considered as exclusion criteria those who did not fit these categories. The participation of the subjects was voluntary, safeguarding the ethical principles of research, maintaining the anonymity and confidentiality of the interview, if they wished. Data were collected in the period between the months of May and July, 2011.

The technique of structured interview was used, through the application of two instruments. The first consisted of a structured questionnaire to characterize the sociodemographic data, information about the disease, lifestyle, and references to the health team, in addition to knowledge about medication. The second instrument was the Morisky-Green Test (TMG), used to assess the degree of adherence to antihypertensive treatment ${ }^{(14)}$ based on the patient self-report, constituting an instrument with the questions: Have you ever forgotten to take your medication? Are you, at times, careless regarding the time to take your medication? When you have felt good, have you ever stopped taking your medication? Have you ever failed to take the medicine when you felt ill? ${ }^{(15)}$

The first analysis of adherence to antihypertensive drug therapy, as per the TMG protocol ${ }^{(15)}$, was accomplished by considering the positive (yes, 0 points) and negative (no, 
1 point) responses. When interpreting this test, patients reaching a score of four were considered as adherent with the treatment, and those who presented at least one 'yes' for an answer were considered nonadherent.

The TMG analysis classified two groups of patients: adherent and nonadherent. After statistical analysis, these were distributed in absolute frequency and percentage, according to the variables obtained in the first instrument. For the statistical data interpretation, the relationship of nonadherence to pharmacologic therapy with other data collected was examined, including those related to non-pharmacologic treatment. The influence of these variables on the frequency of distribution was analyzed using the chi-square statistic or Fisher exact test, considering a significance level of $p<0.05$. Statistical analyses were performed using the GraphPad Prism 3.0 program.
The research was performed after receiving approval from the Committee on Ethics in Research of the Centro Universitário de Maringá, under registration CAAE 0058.0.299.000-11 and CEP certificate No. 029/2011, and after signing the Terms of Free and Informed Consent by the study participants, according to the norms of Resolution No. 196/96.

\section{RESULTS}

Among the 150 patients evaluated, the prevalence of nonadherence to antihypertensive therapy was $64 \%$ (n =96). The frequency of distribution of adherent and nonadherent subjects related to the sociodemographic variables are presented in Table 1, showing the factors involved in these aspects.

Table 1. Frequency of distribution of adherent and nonadherent patients, according to the sociodemographic variables. Maringá-PR, 2011

\begin{tabular}{|c|c|c|c|c|}
\hline \multirow[b]{2}{*}{ Variables } & \multicolumn{2}{|c|}{ Patients } & \multirow[b]{2}{*}{ Total } & \multirow[b]{2}{*}{ p-value } \\
\hline & $\begin{array}{c}\text { Adherent } \\
\text { n (\%) }\end{array}$ & $\begin{array}{c}\text { Non } \\
\text { adherentn }(\%)\end{array}$ & & \\
\hline \multicolumn{5}{|l|}{ Gender } \\
\hline Male & $13(27.1)$ & $35(72.9)$ & 48 & \multirow{2}{*}{0.1456} \\
\hline Female & $41(40.2)$ & $61(59.8)$ & 102 & \\
\hline \multicolumn{5}{|l|}{ Educational level } \\
\hline Illiterate & $07(50.0)$ & $07(50.0)$ & 14 & \multirow{4}{*}{0.4375} \\
\hline Primary education & $31(32.6)$ & $64(67.4)$ & 95 & \\
\hline High school & $15(41.7)$ & $21(58.3)$ & 36 & \\
\hline College education & $01(20.0)$ & $04(80.0)$ & 05 & \\
\hline \multicolumn{5}{|l|}{ Age range } \\
\hline $18-40$ years & $03(20.0)$ & $12(80.0)$ & 15 & \multirow[t]{3}{*}{$0.0143^{*}$} \\
\hline $41-60$ years & $17(26.6)$ & $47(73.4)$ & 64 & \\
\hline$>60$ years & $34(47.9)$ & $37(52.1)$ & 71 & \\
\hline \multicolumn{5}{|l|}{ Working } \\
\hline Yes & $16(25.4)$ & 47 (73.6) & 63 & \multirow[t]{2}{*}{$0.0254^{* *}$} \\
\hline No & $38(43.7)$ & $49(56.3)$ & 87 & \\
\hline \multicolumn{5}{|l|}{ Marital status } \\
\hline Single/widowed/divorced & $15(31.3)$ & $33(68.7)$ & 48 & \multirow{2}{*}{0.4680} \\
\hline Married & $39(38.2)$ & $63(61.8)$ & 102 & \\
\hline \multicolumn{5}{|l|}{ Children } \\
\hline None & $07(41.2)$ & $10(58.8)$ & 17 & \multirow{3}{*}{0.4641} \\
\hline 1 or 2 & $24(40.7)$ & $35(59.3)$ & 59 & \\
\hline 3 or more & $23(31.1)$ & $51(68.9)$ & 74 & \\
\hline \multicolumn{5}{|l|}{ Income } \\
\hline$<1 \mathrm{x}$ minimum wage & $10(40.0)$ & $15(60.0)$ & 25 & \multirow{3}{*}{0.7521} \\
\hline $1-3 x$ minimum wage & $28(34.6)$ & $53(65.4)$ & 81 & \\
\hline$>3 \mathrm{x}$ minimum wage & $03(27.3)$ & $08(72.7)$ & 11 & \\
\hline \multicolumn{5}{|l|}{ Housing } \\
\hline Homeowner & $35(42.2)$ & $48(57.8)$ & 83 & \multirow{2}{*}{0.0893} \\
\hline Rented/other & $19(28.4)$ & $48(71.6)$ & 67 & \\
\hline
\end{tabular}

$*$ Statistically significant $(\mathrm{p}<0.05)-$ Chi-Square. ${ }^{*}$ Statistically significant $(\mathrm{p}<0.05)-$ Fisher exact test. 
As shown (Table 1$)$, the age range $(p=0.0143)$ and occupation ( $p=0.0254)$ of the subjects significantly influenced the frequency of distribution of adherent and nonadherent workers. It was observed that the prevalence of nonadherent patients was higher in those with a lower age range (between 18 and 40 years). In terms of occupation, the patients who worked tended to be nonadherent as compared to those who had no occupational labor.

With regard to the variables associated with diseases and lifestyle, the data can be seen in Table 2 .

Table 2. Frequency of absolute distribution and percent of adherent and nonadherent patients according to variables related to diseases, body mass index (BMI) and lifestyle. Maringá-PR. 2011

\begin{tabular}{|c|c|c|c|c|}
\hline \multirow[b]{2}{*}{ Variables } & \multicolumn{2}{|c|}{ Patients } & \multirow[b]{2}{*}{ Total } & \multirow[b]{2}{*}{ p-value } \\
\hline & $\begin{array}{c}\text { Adherent } \\
\mathrm{n}(\%)\end{array}$ & $\begin{array}{c}\text { Non } \\
\text { adherentn (\%) }\end{array}$ & & \\
\hline \multicolumn{5}{|l|}{ Diseases } \\
\hline Other chronic disease - NO & $22(26.2)$ & $62(73.8)$ & 84 & $0.0061 * *$ \\
\hline Other chronic disease - YES & $32(48.5)$ & $34(51.5)$ & 66 & \multirow{3}{*}{$0.0011^{* *}$} \\
\hline Continued use of medication - NO & $15(21.7)$ & $54(78.3)$ & 69 & \\
\hline Continued use of medication - YES & $39(48.1)$ & $42(51.9)$ & 81 & \\
\hline History of AMI - YES & $08(40.0)$ & $12(60.0)$ & 20 & \multirow{2}{*}{0.8032} \\
\hline History of AMI - NO & $46(35.4)$ & $84(64.6)$ & 130 & \\
\hline Family history of CHD - YES & $40(35.0)$ & $74(65.0)$ & 114 & \multirow{2}{*}{0.6942} \\
\hline Family history of $\mathrm{CHD}-\mathrm{NO}$ & $14(38.9)$ & $22(61.1)$ & 36 & \\
\hline \multicolumn{5}{|l|}{ BMI } \\
\hline$\leq 24.9$ & $16(45.7)$ & $19(54.3)$ & 35 & \multirow{3}{*}{$0.0056^{*}$} \\
\hline $25-29.9$ & $25(47.2)$ & $28(52.8)$ & 53 & \\
\hline$\geq 30$ & $13(21.0)$ & $49(79.0)$ & 62 & \\
\hline \multicolumn{5}{|l|}{ Lifestyle } \\
\hline Smoking - NO & $51(37.0)$ & $87(63.0)$ & 138 & \multirow[b]{2}{*}{0.5382} \\
\hline Smoking - YES & $03(23.0)$ & $09(77.0)$ & 12 & \\
\hline Drinking alcohol - NO & $46(40.4)$ & $68(59.6)$ & 114 & \multirow{2}{*}{0.0720} \\
\hline Drinking alcohol - YES & $08(22.2)$ & $28(77.8)$ & 36 & \\
\hline Physical activity - NO & $30(40.0)$ & $45(60.0)$ & 75 & \multirow{2}{*}{0.3952} \\
\hline Physical activity - YES & $24(32.0)$ & $51(68.0)$ & 75 & \\
\hline Inadequate food & $54(36.0)$ & $96(64.0)$ & 150 & \multirow{2}{*}{0.8058} \\
\hline Fruits and vegetables & $47(35.6)$ & $89(64.4)$ & 136 & \\
\hline
\end{tabular}

$*$ Statistically significant $(\mathrm{p}<0.05)-$ Chi-Square. ${ }^{* *}$ Statistically significant $(\mathrm{p}<0.05)-$ Fisher exact test.

Table 2 shows that the prevalence of nonadherent hypertensive patients was significantly higher among the obese $(p=0.0056)$, indicated by body mass index (BMI) greater than 30. It was also found that the absence of other chronic disease $(p=0.0061)$ and the nonconsumption of medications of continuous use $(p$
$=0.0011)$ were associated with nonadherence.

Factors related to the confidence of patients in the healthcare team and to pharmacological therapy and its influence on the prevalence of adherent and nonadherent hypertensive patients can be observed in the data in Tables 3 and 4, respectively. 
Table 3. Distribution of adherent and nonadherent patients according to confidence in the team, understanding and consultations. Maringá-PR. 2011

\begin{tabular}{|c|c|c|c|c|}
\hline \multirow[b]{2}{*}{ Variables } & \multicolumn{2}{|c|}{ Patients } & \multirow[b]{2}{*}{ Total } & \multirow[b]{2}{*}{ p-value } \\
\hline & $\begin{array}{c}\text { Adherent } \\
n(\%)\end{array}$ & $\begin{array}{c}\text { Non } \\
\text { adherentn }(\%)\end{array}$ & & \\
\hline \multicolumn{5}{|l|}{ Confidence } \\
\hline Confidence in the physician $-\mathrm{NO}$ & $03(23.0)$ & $10(77.0)$ & 13 & \multirow{2}{*}{0.3787} \\
\hline Confidence in the physician - YES & $51(37.2)$ & $86(62.8)$ & 137 & \\
\hline Confidence in the health team $-\mathrm{NO}$ & $04(33.3)$ & $08(66.7)$ & 12 & \multirow{2}{*}{1.000} \\
\hline Confidence in the health team - YES & $50(36.2)$ & $88(63.8)$ & 138 & \\
\hline \multicolumn{5}{|l|}{ Understanding } \\
\hline Understands the recommendations $-\mathrm{NO}$ & $08(20.0)$ & $32(80.0)$ & 40 & \multirow{2}{*}{$0.0202^{*}$} \\
\hline Understands the recommendations - YES & $46(41.8)$ & $64(58.2)$ & 110 & \\
\hline Questions clarified - NO & $11(25.0)$ & $33(75.0)$ & 44 & \multirow{2}{*}{0.0925} \\
\hline Questions clarified - YES & $43(40.6)$ & $63(59.4)$ & 106 & \\
\hline Physician asks about medication use $-\mathrm{NO}$ & $05(33.3)$ & $10(66.7)$ & 15 & \multirow{2}{*}{1.000} \\
\hline Physician asks about medication use - YES & $48(36.9)$ & $82(63.1)$ & 130 & \\
\hline Orientation - physician & $44(41.5)$ & $62(58.5)$ & 106 & \multirow{4}{*}{0.8232} \\
\hline Orientation - pharmacist & $16(42.1)$ & $22(57.9)$ & 38 & \\
\hline Orientation - nurse & $03(27.3)$ & $08(72.7)$ & 11 & \\
\hline Orientation - health agent / other & $05(38.5)$ & $08(61.5)$ & 13 & \\
\hline \multicolumn{5}{|l|}{ Consultation } \\
\hline It forms part of the HiperDia - NO & $37(32.5)$ & $77(67.5)$ & 114 & \multirow{2}{*}{0.1158} \\
\hline It forms part of the HiperDia - YES & $17(47.2)$ & $19(52.8)$ & 36 & \\
\hline 6 months without consultation & $05(41.7)$ & $07(58.3)$ & 12 & \multirow{4}{*}{0.3433} \\
\hline 6 months: 1 consultation & $14(36.8)$ & $24(63.2)$ & 38 & \\
\hline 6 months: $2-3$ consultations & $29(40.3)$ & $43(59.7)$ & 72 & \\
\hline 6 months $>3$ consultations & $06(21.4)$ & $22(78.6)$ & 28 & \\
\hline
\end{tabular}

*Statistically significant $(\mathrm{p}<0.05)$ - Fisher exact test.

The lack of understanding of the patients regarding antihypertensive medication used $(\mathrm{p}=0.0311)$ (Table recommendations about therapy $(\mathrm{p}=0.0202)$ (Table 3$)$, 4), were also considered determinants for therapeutic and the lack of knowledge concerning the name of the nonadherence.

Table 4. Distribution of adherent and nonadherent patients to therapy, according to use and knowledge of the medication. Maringá-PR. 2011

\begin{tabular}{|c|c|c|c|c|}
\hline \multirow[b]{2}{*}{ Variables } & \multicolumn{2}{|c|}{ Patients } & \multirow[b]{2}{*}{ Total } & \multirow[b]{2}{*}{ p-value } \\
\hline & $\begin{array}{c}\text { Adherent } \\
\text { n (\%) }\end{array}$ & $\begin{array}{c}\text { Non } \\
\text { adherentn (\%) }\end{array}$ & & \\
\hline \multicolumn{5}{|l|}{ Medication use } \\
\hline Only 1 antihypertensive & $32(39.0)$ & $50(61.0)$ & 82 & \multirow{2}{*}{0.4948} \\
\hline More than 1 antihypertensive & $22(32.8)$ & $45(67.2)$ & 67 & \\
\hline \multicolumn{5}{|l|}{ Knowledge } \\
\hline Medicine name - YES & $52(39.4)$ & $80(60.6)$ & 132 & \multirow{2}{*}{$0.0311^{`}$} \\
\hline Medicine name - NO & $02(11.8)$ & $15(88.2)$ & 17 & \\
\hline Dose - KNOWS & $40(39.2)$ & $62(60.8)$ & 102 & \multirow[t]{2}{*}{0.2970} \\
\hline Dose - DOES NOT KNOW & $14(29.8)$ & $33(70.2)$ & 47 & \\
\hline Frequency of use - KNOWS & $52(38.5)$ & $83(61.5)$ & 135 & \multirow{2}{*}{0.0856} \\
\hline Frequency of use - DOES NOT KNOW & $02(14.3)$ & $12(85.7)$ & 14 & \\
\hline Reminder - NO & $49(37.4)$ & $82(62.6)$ & 131 & \multirow{2}{*}{0.6021} \\
\hline Reminder - YES & $05(27.8)$ & $13(72.2)$ & 18 & \\
\hline \multicolumn{5}{|l|}{ Other medications } \\
\hline Already changed medication - YES & $19(28.4)$ & $48(71.6)$ & 67 & \multirow{2}{*}{0.0871} \\
\hline Already changed medication - NO & $35(42.7)$ & $47(57.3)$ & 82 & \\
\hline Medications for other diseases - YES & $25(35.2)$ & $46(64.8)$ & 71 & \multirow{2}{*}{0.8652} \\
\hline Medications for other diseases - NO & $29(37.2)$ & $49(62.8)$ & 78 & \\
\hline
\end{tabular}

*Statistically significant $(\mathrm{p}<0.05)-$ Fisher exact test. 
In addition to the previously mentioned findings, other data listed in the tables can be highlighted for assisting in the analysis, although not showing statistical significance. With regard to gender, $72 \%$ of men did not adhere to therapy. Regarding lifestyle, the majority of the patients that maintained their smoking habits $(77 \%)$, drinking alcoholic beverages, $(77.8 \%)$ or not practicing any physical activity (60\%), also did not adhere to pharmacologic treatment. It is important to note that the majority of respondents $(76 \%)$ were not part of the HiperDia program (Sistema de Cadastramento e Acompanhamento de Hipertensos e Diabéticos - Registration and Monitoring System for Hypertensive and Diabetics patients), among which $67 \%$ were nonadherent. On the other hand, $75 \%$ of those that had questions that had not yet been clarified, did not have adherence to the treatment

\section{DISCUSSION}

Although there are currently a large number of pharmacologic and non-pharmacologic methods for the treatment of HTN, adherence to treatment is a major challenge for the health care teams. Different studies have been conducted in order to characterize this adherence. However, it is worth mentioning that the prevalence data on adherence to antihypertensive therapy was varied and this may be related to differences in the populations studied and the measurement instruments used to assess adherence.

The difference of values depending on the instrument used was investigated in a study that used three indirect methods for assessing adherence of individuals to antihypertensive treatment: patient assessment, physician assessment, and the Morisky-Green Test (TMG). These tests provided, respectively, $80.5 \%, 52 \%$, and $51 \%$ of adherence ${ }^{(16)}$. Another study found the prevalence of nonadherence of $8.7 \%$ with the Haynes-Sackett rating scale, $43.4 \%$ with the TMG rating scale, and also $43.4 \%$ in manual counting of tablets and clinical outcome ${ }^{(15)}$.

In this sense, a limitation of the study can be considered, because although such research demonstrates variations in the results, according to the scale applied, the Morisky-Green test was specifically chosen as a tool to assess adherence to treatment, due to its low cost, considerable predictive value ${ }^{(17)}$ and its being adequate to the purpose of the investigation. Another limitation is that was not possible to evaluate if the lack of commitment of hypertensive therapy was associated with failure to maintain BP levels considered optimal. This review requires indirect measures of $\mathrm{BP}$ in ambulatory blood pressure monitoring (MAPA), considered the most sensitive method to monitor patient adherence to antihypertensive therapy, ${ }^{(18)}$ but it was not available at this PCU.

Despite these limitations, this study demonstrated a high prevalence, with $64 \%$ of patients nonadherent to antihypertensive therapy, evidenced by the TMG, which made it possible to highlight important factors pertinent to this nonadherence.

The younger patients (18-40 years) presented lower levels of adherence compared to those in older age groups. This may be related to the fact that HTN is a silent disease and, thus, leads to a certain nonchalance in younger individuals regarding the control of the disease, who only give importance to adequate treatment when there is a worsening of symptoms, increasing risks of serious complications and mortality for stroke and MI.

The results of our study showed no statistically significant relationship between family income, gender, and family history of $\mathrm{CHD}$ with greater adherence to therapy. Still, we would emphasize that despite the prevalence of females in the research, the study data showed that $72 \%$ of interviewed men were nonadherent to therapy, which requires emphasis on human health, due to the current high rate of mortality among men with CHD in Brazil.

In the study, those who still worked were less adherent than those who did not work. This finding requires attention because research shows that $81.5 \%$ of university employees recognized their condition, but only $77.8 \%$ were treated; of these, $60.1 \%$ had controlled BP ${ }^{(19)}$. If we consider that the economically active population is younger, it is possible that these two variables are complementary and contribute to nonadherence.

There is an important relationship to nonadherence to antihypertensive therapy in overweight individuals. The prevalence of nonadherence was significantly higher $(79 \%)$ in patients with a BMI indicating obesity. Note that $60 \%$ of those who were not practicing physical activity, likewise did not adhere to treatment. We have to rethink the strategy of supporting adherence, of encouragement, and guidelines for light and moderate physical activity. In that sense, other studies support a prevalence of nonadherence to antihypertensive therapy strongly associated with patients who did not exercise and who were within lower social classes ${ }^{(20)}$, adding other significant factors such as: younger age, female gender, knowledge of the disease, and family history of CHD ${ }^{(21)}$.

Studies have shown that most nonadherent patients are overweight $(39.1 \%)$ or obese $(43.2 \%)^{(22)}$. There is a prevalence of HTN in the young, also significantly associated to the BMI indicators of overweight and obesity, alcohol consumption, smoking, and physical inactivity ${ }^{(23)}$.

With regard to lifestyle, it should be noted that among patients who had habits of smoking and alcohol consumption, about $77 \%$ were nonadherent to pharmacological treatment. It must be said that the change of habits and lifestyle of hypertensive patients should be emphasized as part of therapeutic assistance, since adopting a healthy lifestyle and practicing physical activity contribute significantly to the reduction in $\mathrm{BP}$, and assist 
in the reduction of or maintenance of weight, and reduce cardiovascular risks.

One of the factors associated with low adherence was the lack of patients' understanding of the health team recommendations. This fact should be considered because the necessary recommendations may not have been transmitted in comprehensible language, or they may have insufficient knowledge about the disease and the severity of its complications, leading them not to consider the recommendations with due seriousness.

Studies confirm a positive association between the patient's knowledge about the disease and compliance with medical recommendations regarding adherence; the main difficulty was to follow a low sodium diet ${ }^{(24)}$. Ignorance about the therapy and the disease itself were associated with low levels of adherence in research in which only $12 \%$ had some knowledge about HTN, and $56 \%$ partially understood its consequences ${ }^{(25)}$.

Although the present study does not show a relationship between educational level and nonadherence to therapy, this relationship was found in other studies ${ }^{(26)}$. Thus, it is important for the health care team to establish strategies for education and counseling of these clients, using appropriate language, because studies ${ }^{(27)}$ indicated that the lower the education level, the lower the patients' understanding of the information received.

On the other hand, only having knowledge of the disease and its treatment are insufficient to ensure good adherence to therapy. Studies indicated uncontrolled $\mathrm{BP}$ in $85 \%$ of men and $74 \%$ of women, even though most had high levels of knowledge about the disease and treatment. Factors associated with nonadherence were: lack of guidance, and a belief that they only had to take the medicine when they felt ill ${ }^{(22)}$, indicating some inconsistency regarding adherence, because, if one had a high knowledge level she/he should not consider using medicines only in hypertensive crises. In contrast, in our study the patients did not have good knowledge about therapy, since the vast majority did not even know the name of the medication used, and this contributed significantly to nonadherence to pharmacological therapy.

The absence of other chronic disease and the fact that the patients did not consume medications requiring continuous use were significantly related to nonadherence. Although no studies were found that assessed this relationship, we believe that having another chronic disease may arouse more concern about health and quality of life, increasing adherence. The continued use of other medications could also facilitate the adherence to the use of medications for reducing BP.

We highlight a significant lack of participation of patients in the HiperDia program (76\%), and of these, $67 \%$ were nonadherent, which requires attention, because the approach to these groups promotes the tracking of risk con- ditions, actions for prevention, and promotes the knowledge of the user's profile and the requirements for interventions.

The involvement of healthcare professionals, particularly nurses, in health education and the awareness of hypertensive patients in relation to their disease and pharmacologic and nonpharmacologic therapies is essential for increasing adherence.

A comparative study among groups of individuals with HTN enrolled in a traditional program and another within the FHP demonstrated that the patients served by the FHP had a significant reduction in systolic BP, which is associated with the fact that the FHP presented a differentiated service with connection between patients and the health care team. They were assisted through nursing consultation and participated in community groups, in which they received frequent orientations about healthcare ${ }^{(28)}$. In another study, after involvement with the FHP, adequate control of BP increased from $28.9 \%$ to $57 \%{ }^{(3)}$, thus emphasizing the importance of nurses in hypertension management and integration among professionals in the healthcare team.

The relationship between the healthcare team and its clientele includes the main factors for nonadherence to treatment, especially the physician-patient relationship, and the organization and structure of the PCU ${ }^{(29)}$. The nurse, because of his/her closer contact with the patient, can establish this bond through nursing consultations.

The adoption of educational strategies with a view toward patient adherence becomes important, and requires patience and dedication on the part of the professional. Health education brings satisfactory results in the prevention and promotion of health, making people healthier, contributing to the reduction of risks of cardiovascular and renal disease in hypertensive patients, and consequently decreasing the number of debilitations and deaths, as well as preventive measures and healthy habits that improve the quality of life of the population and reduce costs.

\section{CONCLUSION}

The research showed a considerably elevated prevalence of nonadherence to therapy (64\%), significantly associated with those in the youngest age group, those who worked, those presenting with overweight or obesity, those who had no other chronic disease nor consumed prescription medications continuously, and those with less knowledge regarding their illness and therapy. On the other hand, among those patients with inadequate food, that still maintained smoking habits, ingested alcoholic beverages or were sedentary, we noted a tendency toward nonadherence.

Despite the fact that the study constituted an epidemiological inquiry about the prevalence of low adherence to antihypertensive therapy and the factors associated with this problem, it is important to test interventions to improve adherence, which is a limitation of the study. However, 
research enables guiding interventions for these patients, in addition to supporting other studies about the implementation of strategies, including education, in this context.

It is worth valuing the inclusion of patients into the HiperDia program as an important facilitator of adherence, in order to submit a strong interventional proposal to potentiate the control, monitoring and prevention of complications of HTN. An emphasis on behaviors of non-pharmacological treatment, especially nutritional

\section{REFERENCES}

1. Sociedade Brasileira de Cardiologia, Sociedade Brasileira de Hipertensão, Sociedade Brasileira de Nefrologia. VI Diretrizes Brasileiras de Hipertensão. Arq Bras Cardiol. 2010; 95(1 Supl 1):1-51.

2. Brasil. Ministério da Saúde. Departamento de Atenção Básica. Hipertensão arterial sistêmica [Internet]. Brasília: Ministério da Saúde; 2006. (Cadernos de Atenção Básica, 15) [citado 2011 Mar 01]. Disponível em: http://189.28.128.100/dab/ docs/publicacoes/cadernos_ab/abcad15.pdf

3. Araújo JC, Guimarães AC. [Control of arterial hypertension in a family care unit]. Rev Saúde Pública. 2007;41(3):368-4. Portuguese.

4. Fuchs SC. Fatores de risco para hipertensão arterial. In: Brandão AA, Amodeo C, Nobre F, Fuchs FD. Hipertensão. Rio de Janeiro: Elsevier; 2007. p. 27-34.

5. Avezum A, Piegas LS, Pereira JC. Risk factors associated with acute myocardial infarction in the São Paulo metropolitan region. A developed region in a developing country. Arq Bras Cardiol. 2005;84(3):203-13.

6. Brasil. Ministério da Saúde. Hipertensão avança e atinge 24,4\% dos brasileiros [Internet]. 2010. [citado 2011 Mar 7] Disponível em: http://portal.saude.gov.br/portal/ aplicacoes/noticias/default.cfm?pg $=$ dspDetalheNoticia\&id_ area $=124 \&$ CO_NOTICIA $=11290$

7. Brasil. Ministério da Saúde. Sistema de Informações sobre Mortalidade (SIM). Análise dos dados de mortalidade de 2001 [nternet] [citado $2011 \mathrm{Fev}$ 9] Disponível em: http:// portal.saude.gov.br/portal/arquivos/pdf/capitulo4_sb.pdf.

8. Brasil. Ministério da Saúde. Sala de situação em saúde [Internet]. 2009 [citado 2010 Fev 21]. Disponível em: $<$ http://portal.saude.gov.br/portal/saude/default.cfm>.

9. Amodeo C, Helene EV. Manual do comportamento do hipertenso: uma visão psicológica para a prática clínica da hipertensão. São Paulo: Segmento; 2000.

10. Lopes HF, Barreto-Filho JA, Riccio GM. Tratamento nãomedicamentoso da hipertensão arterial. São Paulo: Rev Soc Cardiol Estado de São Paulo. 2003;13(1):148-55.

11. Hoffman BB. Terapia da hipertensão. In: Brunton LL, Lazo J, Parker KL. Goodman \& Gilman: as bases farmacológicas da terapia. 10a ed. Rio de Janeiro: Mc Graw Hill; 2006. p. 757-77.

12. Gusmão JL, Ginani GF, Silva GV, Ortega KC, Mion Junior D. [Adhesion to the treatment in systolic hypertension]. Rev Bras Hipertens. 2009;16(1):38-43. Portuguese.

13. Coutinho FH. Percepção dos portadores de hipertensão arterial sobre a doença e sua adesão ao tratamento na estratégia de saúde da família [monografia]. Recife: Fundação Oswaldo Cruz, Centro de Pesquisas Ageu Magalhães; 2010.

14. Ungari AQ. Adesão ao tratamento farmacológico de pacientes hipertensos seguidos nos núcleos de saúde da família de Ribeirão Preto São Paulo [dissertação]. Ribeirão Preto: Universidade de São Paulo, Faculdade de Medicina; 2007.

15. Santa Helena ET, Nemes MI, Eluf-Neto J. Development and validation of a multidimensional questionnaire assessing non- reeducation, physical activity, smoking cessation, among others, is also suggested.

Emphasis is therefore needed for greater participation of health professionals, especially nurses, both in action planning and staff training, as well as insightful approaches during the pre-consultation and home visits. Through health education programs, the team can promote awareness in these patients about the disease, risks and complications aimed at changes in lifestyle and better adherence to antihypertensive therapy.

adherence to medicines. Rev Saúde Pública. 2008;42(4):764-7.

16. Bloch KV, Melo AN, Nogueira AR. [Prevalence of antihypertensive treatment adherence in patients with resistant hypertension and validation of three indirect methods for assessing treatment adherence]. Cad Saúde Pública. 2008;24(12):2979-84. Portuguese.

17. Morisky DE, Green LW, Levine DM. Concurrent and predictive validity of a self-reported measure of medication adherence. Med Care. 1986; 24(1):67-74.

18. Sociedade Brasileira de Cardiologia. V Diretrizes Brasileiras de Monitorização Ambulatorial da Pressão Arterial (MAPA) e III Diretrizes de Monitorização Residencial da Pressão Arterial (MRPA). Arq Bras Cardiol. 2011; 97(3 Supl 3):1-24.

19. Nogueira D, Faerstein E, Coeli CM, Chor D, Lopes CS, Werneck GL. Awareness, treatment, and control of arterial hypertension: Pró-Saúde study, Brazil. Rev Panam Salud Pública. 2010; 27(2):103-9.

20. Santa Helena ET, Nemes MI, Eluf-Neto J. [Evaluation of care provided for people with arterial hypertension in family health strategy services]. Saúde Soc. 2010;19(3):614-26. Portuguese.

21. Pierin AM, Marroni SN, Taveira LA, Benseñor IJ. Hypertension control and related factors at primary care located in the west side of the city of São Paulo, Brazil. Ciênc Saúde Coletiva. 2011;16 Supl 1:1389-400.

22. Jesus ES, Augusto MA, Gusmão J, Mion Junior D, Ortega K, Pierin AM. Profile of hypertensive patients: biosocial characteristics, knowledge, and treatment compliance. Acta Paul Enferm. 2008; 21(1):59-65.

23. Jardim PC, Gondim MR, Monego ET, Moreira HG, Vitorino PV, Souza WK, ET al. High blood pressure and some risk factors in a Brazilian capital. Arq Bras Cardiol. 2007; 88(4):452-7.

24. Figueiredo NN, Asakura L. [Adherence to antihypertensive treatment: difficulties reported by hypertensive patients]. Acta Paul Enferm. 2010;23(6):782-7. Portuguese.

25. Santos ZM, Frota MA Cruz DM, Holanda SD. Hypertensive client adhesion to their treatment: an analysis with an interdisciplionary approach. Texto \& Contexto Enferm. 2005;14(3):332-40.

26. Vitor AF, Monteiro FP, Morais HC, Vasconcelos JD, Lopes MV, Araújo TL. [Survey of the follow-therapeutic patients with hypertension]. Esc Anna Nery Rev Enferm. 2011;15(2):251-60.

27. Oliveira JC. Idosos em tratamento farmacológico antihipertensivo: parâmetros para o cuidado clínico de enfermagem [dissertação]. Fortaleza: Universidade Estadual do Ceará, Escola de Enfermagem; 2007.

28. Mano GM, Pierin AM. [Evaluation from the hypertensive patients followed in the Family Health Program at Health School Center]. Acta Paul Enferm. 2005;18(3):269-75. Portuguese.

29. Duarte MT, Cyrino AP, Cerqueira AT, Nemes MI, Iyda M. [Reasons for medical follow-up dropout among patients with arterial hypertension: the patient's perspective]. Ciênc Saúde Coletiva. 2010;15(5):2603-10. Portuguese. 